\title{
Assessment of the degree of satisfaction of physical therapy students with the academic experience
}

\author{
Verificação da satisfação com a experiência \\ acadêmica de estudantes de fisioterapia
}

\section{Francieli do Nascimento Czapievski ${ }^{[a]}$, Alberto Sumiya ${ }^{[b]}$}

[a] Physiotherapist, Universidade Estadual do Centro-Oeste (Unicentro), Guarapuava, PR - Brazil, e-mail: franczap@gmail.com

[b] Physiotherapy professor at the State University of West Parana (Unioeste), PhD student in Motricity Sciences, Universidade Estadual Paulista "Júlio de Mesquita Filho" (Unesp), Rio Claro, SP - Brazil, e-mail: asumiya@hotmail.com,

\begin{abstract}
Introduction: The demand for higher education in Brazil has grown in recent decades, leading to teaching, pedagogical and structural changes in the public and private education sectors. Assessments of academic experience evaluate the quality of services provided within the fields of learning, relationships and infrastructure. Objective: To assess the degree of satisfaction with their academic experience of students from all years of the undergraduate physical therapy course. Materials and Methods: Cross-sectional research with 137 students from four years of the physical therapy course. The Scale of Satisfaction with Academic Experience was used, which contains 35 questions and is divided into three dimensions. Results: The 1styear students were the most satisfied (121.43 \pm 18.68$)$, followed by the 3rd-year (118.97 \pm 25.37$)$, then the 2nd (118.50 \pm 28.28$)$ and 4th-year students (103.02 \pm 28.66$)$. Conclusion: The results were consistent with the literature regarding the limited experience of 1st-year students within the institution, which influences their evaluation, as it shows an incipient interaction with problems that permeate the course. On the other hand, the 4th-year students showed a more critical view due to the expectations of the fight for a place in the labor market.
\end{abstract}

Keywords: Personal satisfaction. Students. Physical therapy specialty. 


\section{Resumo}

Introdução: A procura por formação universitária no Brasil cresceu nas últimas décadas, o que provocou mudanças didático-pedagógicas e estruturais nos setores públicos e privados da educação. As avaliações da experiência acadêmica verificam a qualidade dos serviços prestados no âmbito do aprendizado, das relações e da infraestrutura. Objetivo: Avaliar a satisfação com a experiência acadêmica de estudantes de diferentes turmas da graduação em fisioterapia. Materiais e métodos: Pesquisa transversal com 137 alunos, distribuídos nas quatro séries do curso. Utilizou-se a Escala de Satisfação com a Experiência Acadêmica, que contém 35 perguntas, divididas em três dimensões. Resultados: Os alunos do $1^{\circ}$ ano são os mais satisfeitos $(121,43 \pm 18,68)$, seguidos respectivamente pelo $3^{\circ}$ ano $(118,97 \pm 25,37)$, pelo $2^{\circ}$ ano $(118,50 \pm 28,28)$ e pelo $4^{\circ}$ ano $(103,02 \pm$ 28,66). Conclusão: Observou-se que os resultados encontrados estão de acordo com a literatura no que tange à pouca vivência do $1^{\circ}$ ano dentro da instituição, o que influencia sua avaliação, pois evidencia interação ainda incipiente dos problemas que permeiam o curso. No extremo oposto, o $4^{\circ}$ ano evidencia uma visão mais crítica, graças às expectativas das disputas de espaço no mercado profissional.

Palavras-chave: Satisfação pessoal. Estudantes. Fisioterapia.

\section{Introduction}

The development of a country depends on the improvement of the level of schooling and its suitability in regards to the productive system. Recently, there has been an increase in the academic population in Brazil, and that is why the government is committed to expand the availability offer and promote higher education for all (1). A good quality education is also necessary as well as diversification of courses, qualification of teaching staff, funding guarantees, employability of graduates and young workers, and research promotion $(2,3)$. These are goals that require the involvement of society as a whole.

The quality assurance of higher education relies on internal and external evaluations that aim to prevent or implement changes. Some indicators such as degrees, working scheme, and publications seem to be insufficient as they put aside other aspects of education assessment, which is a concept with several layers. Therefore, higher education institutions must be prepared to acknowledge a wide range of individual differences in which adaptations that go beyond technological innovations must be implemented in order to consolidate new learning spaces and to promote, throughout the training process, a full development whether cognitive, vocational, or personal - where a collective reflection process takes place (4).

In order to practically acknowledge the differences, it is necessary to consider the students' opinions about the different aspects of their course, as the offer is highly standardized, and the courses only cover basic matters that ensure their general functioning. They provide a traditional curricular content with traditional teaching methods that are not efficient in the current information era (5).

In this way, academic performance cannot be assessed only using grades or evaluation of skills. The idea of academic success goes beyond that. It concerns all of a student's experiences in the educational environment with satisfactory or unsatisfactory achievements (6). To achieve the goals of a new education that go beyond practical recasting, it is necessary for the student to be actively involved.

The physical therapy course at Unicentro University in the city of Guarapuava, Paraná, was first offered in 1999. Since then, the curricular contents have been reshaped three times, the latest changes done in 2010. The aim of this article is to assess the degree of satisfaction of students from all years of the undergraduate physical therapy course with their academic experience at Unicentro.

\section{Materials and methods}

This is a cross-sectional study that aims to assess the degree of satisfaction of physical therapy students from Unicentro by means of the Scale of Satisfaction with Academic Experience (ESEA, as per its acronym in Portuguese), which was validated by Schleich, Polydoro, and Santos (7), who reported 
that this instrument explained $47.7 \%$ of the total variance and 0.942 of internal consistency. The three dimensions of the ESEA, as explained below, have Cronbach's alphas of 0.902, 0.865, and 0.866, respectively (4).

ESEA $(4,7)$ consists of 35 questions rated between 1 and 5 where 1 means "not satisfied at all" and 5 means "completely satisfied," and only the lowest and highest rates are presented. The instrument is divided into three dimensions: a) satisfaction with the course (questions 1, 5, 8, 12, 13, 14, 21, 25, 28, 31, 33, 34, and 35 ) - minimum rating 13 , maximum 65 ; b) development opportunity $(2,3,6,9,10,11,17,23,24$, and 26 ) - minimum rating 10 , maximum 50 ; and c) satisfaction with the institution $(4,7,15,16,18,19,20,22$, 27, 29, 30, and 32) - minimum rating 12, maximum 60.

The survey was carried out in 2010, and the sample consisted of 137 students who were apportioned as follows: $1^{\text {st }}$ year with 30 students; $2^{\text {nd }}$ year with 36 ; $3^{\text {rd }}$ year with 35 , and $4^{\text {th }}$ year with 36 . Inclusion criteria were: 1) to be duly enrolled in the physical therapy course; 2) to sign the Free and Informed Consent Form; 3) to be physically able to mark the answers without any help; 4) to fill in the ESEA (4, 7) only in the classroom during the general collection, for all school years. The exclusion criterion was failure to meet the inclusion criteria.

The ESEA $(4,7)$ was conducted with Unicentro students during a theoretical class each school year. To avoid rushing the students, there was no established deadline for the answers, but the evaluation could not last longer than a lesson. In order to avoid bias, students were asked not to exchange information and to remain silent. The data were analyzed by assessing the reliability of arithmetic means with the help of BioStat 4.5 software. Only the questionnaires that were fully answered were analyzed.

This work was approved by the Human Research Ethics Committee from Unicentro under number $420 / 2010$.

\section{Results}

The total number of participants was 137 out of which 111 were females and 26 were males with an average age of $20.60 \pm 2.83$. After dividing individuals by year, we counted 22 women and 8 men in the $1^{\text {st }}$ year (19.34 \pm 3.58 years old), 31 women and 5 men in the $2^{\text {nd }}$ year (19.33 \pm 1.10 years old $), 29$ women and 6 men in the $3^{\text {rd }}$ year $(21.08 \pm 2.42$ years old $)$, and 29 women and 7 men in the $4^{\text {th }}$ year $(22.44 \pm$ 2.64 years old).

Table 1 shows raw data of scores by course year divided into the three dimensions of ESEA (7) components, so a first and separate analysis of the results obtained was possible. It is worth mentioning that the ESEA (7) has no cut-off score to determine dissatisfaction; instead, there is more or less satisfaction when the arithmetic means are compared.

Table 1 - Raw data distribution per dimension in each year

(To be continued)

\begin{tabular}{|c|c|c|c|c|c|c|c|c|c|c|c|}
\hline \multicolumn{12}{|c|}{ Undergraduate } \\
\hline \multicolumn{3}{|c|}{$1^{\text {st }}$ year } & \multicolumn{3}{|c|}{$2^{\text {nd }}$ year } & \multicolumn{3}{|c|}{$3^{\text {rd }}$ year } & \multicolumn{3}{|c|}{$4^{\text {th }}$ year } \\
\hline $1^{\text {st }}$ & $2^{\text {nd }}$ & $3^{\text {rd }}$ & $1^{\text {st }}$ & $2^{\text {nd }}$ & $3^{\text {rd }}$ & $1^{\text {st }}$ & $2^{\text {nd }}$ & $3^{\text {rd }}$ & $1^{\text {st }}$ & $2^{\text {nd }}$ & $3^{\text {rd }}$ \\
\hline 60 & 35 & 51 & 26 & 15 & 13 & 29 & 15 & 15 & 20 & 10 & 11 \\
\hline 50 & 36 & 44 & 31 & 18 & 15 & 36 & 18 & 20 & 26 & 13 & 13 \\
\hline 41 & 29 & 37 & 36 & 20 & 18 & 37 & 20 & 24 & 27 & 14 & 14 \\
\hline 58 & 41 & 48 & 38 & 22 & 20 & 37 & 22 & 25 & 28 & 14 & 15 \\
\hline 51 & 31 & 26 & 39 & 23 & 22 & 39 & 22 & 26 & 29 & 15 & 17 \\
\hline 40 & 30 & 38 & 40 & 23 & 24 & 42 & 24 & 28 & 32 & 19 & 17 \\
\hline 55 & 41 & 47 & 40 & 23 & 27 & 42 & 25 & 32 & 33 & 19 & 19 \\
\hline 54 & 37 & 40 & 40 & 25 & 28 & 44 & 25 & 32 & 35 & 19 & 21 \\
\hline 42 & 29 & 38 & 41 & 26 & 30 & 44 & 26 & 32 & 35 & 21 & 24 \\
\hline 40 & 18 & 27 & 41 & 28 & 31 & 44 & 28 & 33 & 37 & 21 & 25 \\
\hline
\end{tabular}


Table 1 - Raw data distribution per dimension in each year

(Conclusion)

\begin{tabular}{|c|c|c|c|c|c|c|c|c|c|c|c|}
\hline \multicolumn{12}{|c|}{ Undergraduate } \\
\hline \multicolumn{3}{|c|}{$1^{\text {st }}$ year } & \multicolumn{3}{|c|}{$2^{\text {nd }}$ year } & \multicolumn{3}{|c|}{$3^{\text {rd }}$ year } & \multicolumn{3}{|c|}{$4^{\text {th }}$ year } \\
\hline $1^{\text {st }}$ & $2^{\text {nd }}$ & $3^{\text {rd }}$ & $1^{\text {st }}$ & $2^{\text {nd }}$ & $3^{\text {rd }}$ & $1^{\text {st }}$ & $2^{\text {nd }}$ & $3^{\text {rd }}$ & $1^{\text {st }}$ & $2^{\text {nd }}$ & $3^{\text {rd }}$ \\
\hline 49 & 34 & 35 & 44 & 28 & 31 & 45 & 30 & 33 & 39 & 22 & 25 \\
\hline 44 & 30 & 35 & 46 & 28 & 31 & 45 & 30 & 34 & 40 & 23 & 27 \\
\hline 52 & 42 & 54 & 46 & 30 & 33 & 46 & 30 & 34 & 41 & 23 & 28 \\
\hline 53 & 37 & 51 & 48 & 30 & 35 & 47 & 30 & 35 & 41 & 23 & 28 \\
\hline 40 & 34 & 41 & 48 & 32 & 36 & 47 & 31 & 35 & 41 & 24 & 29 \\
\hline 46 & 33 & 44 & 49 & 33 & 36 & 48 & 31 & 36 & 42 & 27 & 31 \\
\hline 44 & 33 & 34 & 50 & 33 & 36 & 49 & 32 & 37 & 42 & 28 & 32 \\
\hline 46 & 33 & 37 & 51 & 33 & 36 & 52 & 32 & 37 & 42 & 28 & 32 \\
\hline 54 & 31 & 36 & 51 & 33 & 37 & 52 & 33 & 38 & 43 & 28 & 32 \\
\hline 52 & 36 & 50 & 51 & 34 & 39 & 53 & 33 & 38 & 43 & 30 & 32 \\
\hline 48 & 33 & 45 & 51 & 35 & 40 & 53 & 33 & 39 & 43 & 30 & 32 \\
\hline 61 & 41 & 45 & 52 & 35 & 43 & 53 & 33 & 40 & 45 & 31 & 33 \\
\hline 55 & 38 & 40 & 52 & 35 & 43 & 53 & 33 & 42 & 46 & 31 & 33 \\
\hline 60 & 39 & 49 & 54 & 35 & 44 & 53 & 33 & 43 & 47 & 32 & 35 \\
\hline 33 & 27 & 28 & 56 & 35 & 44 & 54 & 33 & 44 & 48 & 32 & 35 \\
\hline 42 & 25 & 27 & 56 & 36 & 44 & 55 & 35 & 45 & 48 & 32 & 37 \\
\hline 39 & 29 & 43 & 56 & 37 & 45 & 57 & 36 & 45 & 49 & 32 & 39 \\
\hline 39 & 29 & 30 & 56 & 39 & 46 & 57 & 36 & 45 & 50 & 32 & 39 \\
\hline 51 & 34 & 36 & 56 & 39 & 46 & 57 & 37 & 48 & 52 & 32 & 40 \\
\hline 45 & 33 & 38 & 57 & 39 & 47 & 58 & 39 & 50 & 53 & 33 & 40 \\
\hline- & - & - & 58 & 39 & 47 & 59 & 39 & 51 & 53 & 33 & 40 \\
\hline- & - & - & 60 & 40 & 50 & 60 & 40 & 51 & 54 & 34 & 41 \\
\hline- & - & - & 63 & 40 & 54 & 61 & 41 & 53 & 54 & 36 & 44 \\
\hline- & - & - & 64 & 43 & 55 & 62 & 43 & 56 & 55 & 38 & 45 \\
\hline- & - & - & 64 & 46 & 57 & 64 & 46 & 60 & 56 & 42 & 47 \\
\hline- & - & - & 65 & 44 & 53 & - & - & - & 59 & 42 & 50 \\
\hline 48.1 & 33.2 & 39.8 & 49.3 & 32.0 & 37.1 & 49.5 & 31.2 & 38.1 & 42.4 & 26.7 & 30.6 \\
\hline 7.32 & 5.26 & 7.76 & 9.32 & 7.43 & 11.2 & 8.33 & 7.01 & 10.17 & 9.37 & 7.96 & 9.98 \\
\hline
\end{tabular}

Source: Research data.

In the $1^{\text {st }}$ dimension of Table 1 , it is observed that the $3^{\text {rd }}$ year students are the most satisfied with the course, followed by the $2^{\text {nd }}, 1^{\text {st }}$, and $4^{\text {th }}$ years. A gradual score decrease is seen starting from the $1^{\text {st }}$ year regarding the satisfaction with development opportunities in the $2^{\text {nd }}$ dimension of the table. Regarding the satisfaction with the institution, the initial behavior was similar to the development opportunities level, but the $3^{\text {rd }}$ year interrupted this evolution.

Table 2 below shows, in a comparative manner, the general result of the analysis of the three dimensions proposed by ESEA and assessed jointly. To evaluate the association between the dimensions, an ANOVA was done with a criterion $(p<0.05)$ in all series $(p<$ 
Table 2 - Degree of satisfaction per year

\begin{tabular}{lrrrr}
\hline Undergraduate & $\mathbf{1}^{\text {st }}$ year & $\mathbf{2}^{\text {nd }}$ year & $\mathbf{3}^{\text {rd }}$ year & 4th year \\
\hline Mean & 121.43 & 118.50 & 118.97 & 103.02 \\
Standard deviation & 18.68 & 28.28 & 25.37 & 28.66 \\
\hline
\end{tabular}

Source: Research data.

$0.001)$. The score results from each year were compared using the Kruskall-Wallis test $(p \leq 0.05)$ to assess the reliability of means within the groups $(p=$ 0.0288 ). The $1^{\text {st }}$-year students are the most satisfied, followed by the $3^{\text {rd }}$, $2^{\text {nd }}$, and $4^{\text {th }}$ - year students.

\section{Discussion}

Entrance into higher education is characterized by many expectations and fears. Courses with a full-time curriculum such as physical therapy require some adaptations from the student in the sociocultural, economic, family, and emotional spheres. To face these conditions is enriching for the construction of personal history, but it can also lead to frustrations that result in learning difficulties, failures, and dropouts $(8,9,10)$. An educational policy that is committed to these ideals of higher education must take these facts into consideration.

The complexity of academic adjustment considers facts that go beyond the classroom walls. Therefore, the processes and means that facilitate learning should not be put out of the whole context of human development. Frustration or satisfaction have an effect on student involvement - that is, the way students dedicate themselves to the course. The relationship between students, teachers, and the organization is important in order to understand the quality of the experience, which ultimately influences the academic performance $(11,12)$.

Adaptation to the university was assessed in a study that evaluated five spheres called career, personal, interpersonal, study, and institutional. The correlations revealed that the variables "self-exploration" and "degree of out-of-class interaction with teachers" were more closely related to the five indicators of adaptation (13). The low degree of correlation with other possible variables maybe responsible for the occurrence of academic dropout, which was around $22 \%$ on average in Brazil between 2000 and 2005 (14).The reasons for dropouts are mainly economic difficulties (15) and disappointment of previous expectations (16).

Santos and Suehiro (17) point out that entering students go through a period of idealization, which reflects higher degrees of academic satisfaction. The lack of actual knowledge of institutional problems makes it difficult to understand the social meaning of the entrance into higher education. On the other hand, they reassert the idea that working on a consistent adaptation has a positive and cumulative effect on academic performance. The $1^{\text {st }}$ undergraduate year of the physical therapy course at Unicentro was comparatively more satisfactory than the other years in all assessed dimensions and in the general result.

Igue, Bariani, and Milanesi (18) analyzed the experiences and expectations of concluding university students via an Academic Experiences Questionnaire (AEQ), showing that concluding students are less satisfied than entering students. The last year course is characterized by the opposition of the initial idealization, goals that were not achieved, and the redefinition of mistaken strategies. These observations are evident in the results of our study when we see the rates of $4^{\text {th }}$-year students who, despite their satisfaction with the course, face the possibility of uncertain professional growth.

There was little difference between the values found for the $2^{\text {nd }}$ and $3^{\text {rd }}$ years, the latter being the most satisfied, which contradicts the statement that the longer the stay in university the less satisfaction students will experience. Bardagi, Lassance, and Paradiso (19) did research on academic backgrounds and satisfaction with professional choices with 391 students from 16 courses. They noticed that the half-course period was the most difficult, although they did not compare entering and concluding students. The authors also indicated that the variable 
involvement with institutional activities is essential to characterize satisfaction. It must be observed, then, that isolated events of dissatisfaction can have a negative effect on academic experience.

The dimension with the highest mean in our study was satisfaction with the course, which is similar to what Schleich, Polydoro, and Santos (7) found. They explain that this result refers mainly to the students' satisfaction with their relationship with teachers, colleagues, and the quality of the course. The physical therapy course at Unicentro has gone through changes that are consistent with these findings. The increasing qualification of the teaching staff, with a larger number of masters and PhD holders brings didactic and pedagogical innovations that have an impact on the way the students see the course.

Currently, the curricular content of Unicentro is going through its third recasting, which shows a maturing in the search for curricular balance whether by rectifying previous mistakes or by implementing innovation. The campus itself is receiving funds to have its infra-structure improved. A follow-up instrument, such as the one proposed by this study, would contribute to keep available the information that is part of the constant process of changes in education but highlighting the student body speech.

\section{Conclusion}

The results found are in accordance with the literature when it comes to the need for greater attention to adaptation factors for entering students and the development of strategies that include the skills needed by the labor market. Academic performance depends on satisfaction during the undergraduate course provided by the institution by qualified teachers, participative management, and a suitable infrastructure for knowledge production.

The dimension called "satisfaction with the course" stood out with higher rates despite the interviewees' dissatisfaction with the institution and a decreasing satisfaction with development opportunities over the years. The regular use of this kind of instrument is recommended at the end of each year as it would work as an aid in the planning of concrete, didactic, and pedagogical strategies.

\section{References}

1. Pinto JMR. 0 acesso à educação superior no Brasil. Educ Soc. 2004;25(88):727-56.

2. Neves CEB. Desafios da educação superior. Sociol. 2007;9(17):14-21.

3. Macedo AR, Trevisan LMV, Trevisan P, Macedo CS. Educação superior no século XXI e a reforma universitária Brasileira. Ensaio aval pol públ Educ. 2005;13(47):127-48.

4. Schleichi ALR. Integração na educação superior e satisfação acadêmica de estudantes ingressantes e concluintes [dissertação]. Campinas: Universidade Estadual de Campinas; 2006.

5. Pereira SE. Contribuições para um planejamento educacional em ciências da saúde com estratégias inovadoras de ensino-aprendizagem. Com Ciências Saúde. 2007;18(1):33-44.

6. Almeida L, Soares AP, Ferreira JA. Questionário de Vivências Acadêmicas (QVA-r): avaliação do ajustamento dos estudantes universitários. Aval Psicol. 2002;1(2):81-93.

7. Schleichi ALR, Polydoro SAJ, Santos AAA. Escala de satisfação com a experiência acadêmica de estudantes do ensino superior. Aval Psicol. 2006;5(1):11-20.

8. Polydoro SAJ, Primi R, Serpa MNF, Zaroni MMH, Pombal KCP. Desenvolvimento de uma escala de Integração ao Ensino Superior. Psico-USF. 2001;6(1):11-7.

9. Vendramini CMM, Santos AAA, Polydoro SAJ, Sbardelini ETB, Serpa MNF, Natário EG. Construção e validação de uma escala sobre avaliação da vida acadêmica (EAVA). Estud Psicol. 2004;9(2):259-68.

10. Cyrino EG, Toralles-Pereira ML. Trabalhando com estratégias de ensino-aprendizado por descoberta na área da saúde: a problematização e a aprendizagem baseada em problemas. Cad Saúde Pública. 2004;20(3):780-08.

11. Soares AP, Almeida LS, Diniz AM, Guisande MA. Modelo multidimensional de ajustamento de jovens ao contexto universitário (MMAU): estudo com estudantes de ciências e tecnologias versus ciências sociais e humanas. Aná Psicológica. 2006;24(1):15-27. 
12. Guerreira-Casanova D, Polydoro S. Integração ao ensino superior: relações ao longo do primeiro ano de graduação. Psicol Ensino \& Form. 2010;1(2):85-96.

13. Teixeira MAP, Castro GD, Piccolo LR. Adaptação à universidade em estudantes universitários: um estudo correlacional. Interação. 2007;11(2):211-20.

14. Silva-Filho RLL, Motejunas PR, Hipólito O, Lobo MBCM. A evasão no ensino superior brasileiro. Cad Pesq. 2007;37(132):641-59.

15. Ribeiro MA. O projeto profissional familiar como determinante da evasão universitária: um estudo preliminar. Rev bras orientac prof. 2005;6(1):55-70.

16. Cunha AM, Tunes E, Silva RR. Evasão do curso de química da universidade de Brasília: a interpretação do aluno evadido. Quim Nova. 2001;24(2):262-80.

17. Santos AAA, Suehiro ACB. Instrumentos de avaliação da integração e da satisfação acadêmica: estudo de validade. Rev galleg-port psicol educ. 2007;14(1):107-19.
18. Igue EA, Bariani ICD, Milanesi PVB. Vivência acadêmica e expectativas de universitários ingressantes e concluintes. Psico-USF. 2008;13(2):155-64.

19. Bardagi MP, Lassance MCP, Paradiso AC. Trajetória acadêmica e satisfação com a escolha profissional de universitários em meio de curso. Rev bras orientac prof. 2003;4(1-2):153-66.

Received: 06/26/2013

Recebido: 26/06/2013

Approved: $11 / 17 / 2013$

Aprovado: 17/11/2013 